\title{
"humanidades
}

Revista Humanidades

ISSN: 2215-3934

humanidades@ucr.ac.cr

Universidad de Costa Rica

Costa Rica

\section{Arte e Estética na Educação: uma Dimensão Epistemológica}

Cunha de Araújo, Gustavo

Arte e Estética na Educação: uma Dimensão Epistemológica

Revista Humanidades, vol. 11, núm. 1, 2021

Universidad de Costa Rica, Costa Rica

Disponible en: http://www.redalyc.org/articulo.oa?id=498064330005

DOI: https://doi.org/10.15517/h.v11i1.44157

\section{c) $(1) \Theta \Theta$}

Esta obra está bajo una Licencia Creative Commons Atribución-NoComercial-SinDerivar 3.0 Internacional, 
Desde el arte, la literatura y la comunicación

\title{
Arte e Estética na Educação: uma Dimensão Epistemológica
}

\author{
Gustavo Cunha de Araújo \\ Universidade Federal do Tocantins, Brasil \\ gustavocaraujo@yahoo.com.br \\ (iD) http://orcid.org/https:// \\ orcid.org/0000-0002-1996-5959
}

El Arte y la Estética en la Educación: una Dimensión Epistemológica

Art and Aesthetics in Education: an Epistemological Dimension

DOI: https://doi.org/10.15517/h.v11i1.44157

Redalyc: http://www.redalyc.org/articulo.oa?

id $=498064330005$

Recepción: 12 Junio 2020

Aprobación: 05 Agosto 2020

\section{Resumo:}

Pesquisas relacionadas às concepções de estética vêm sendo estudadas há bastante tempo na literatura científica. No entanto, são poucas as revisões sistemáticas acerca da estética na educação. Nesse sentido, objetiva-se compreender, a partir de diferentes correntes teóricas, como a estética é concebida e discutida nas ciências humanas, considerando a sua relação com a arte e educação. Seguiu-se a abordagem qualitativa, de caráter descritivo e de natureza bibliográfica. Para as análises dos dados, adotou-se a técnica da pesquisa interpretativa. Os dados teóricos foram construídos a partir de extenso levantamento bibliográfico realizado em artigos e livros a respeito da arte e da estética ao longo de 3 anos. Dentre alguns resultados, os dados revelaram que a estética apresenta diferentes concepções no percurso histórico científico, ora se convergindo com o campo educacional, ora se distanciando desse. Contudo, durante a trajetória escolar ou acadêmica, pode ocorrer do estudante não querer produzir um objeto ou atividade apenas por produzir, ele pode querer fazê-lo bem feito, e isso responde a uma necessidade prática de produção material que o acompanha no percurso histórico da humanidade. Sendo expressão de algo bem definido, coerente e bem resolvido, pode ser entendido como expressão de beleza, pois apresenta qualidade estética.

Palavras-Chave: arte, estética, educação, humanidades.

\section{RESUMEN:}

Las investigaciones con relación al concepto de la estética han sido analizadas durante mucho tiempo desde el campo científico. A pesar de ello, hay pocas revisiones sistemáticas sobre la estética dentro de los sistemas educativos. Esta investigación pretende descifrar como la estética es concebida y discutida desde diferentes teorías de las ciencias humanas, considerando su relación con el arte y la educación. Metodológicamente se sigue el enfoque cualitativo de carácter descriptivo y de naturaleza bibliográfica. Asimismo, para el análisis de datos, se adoptó la técnica de investigación interpretativa. Los datos teóricos se construyeron durante 3 años a partir de una extensa revisión bibliográfica de artículos y libros sobre arte y estética. Los datos revelaron que la estética presenta distintas concepciones en el camino científico-histórico, a veces convergiendo con el campo educativo, a veces distanciándose de él. Ahora bien, durante la carrera escolar, puede ocurrir que el educando no desee elaborar un objeto solo por crear, puede querer confeccionarlo detalladamente, respondiendo a la necesidad práctica de producción material que ha acompañado a la humanidad a través de la historia. De esta forma, al ser una expresión bien definida, coherente y bien resuelta, puede entenderse como una expresión de belleza, porque supone una calidad estética.

Palabras Clave: arte, estética, educación, humanidades.

\section{Abstract:}

Investigations regarding the concept of aesthetic have been analyzed for a long time from the scientific field. However, there are not many scientific studies that relate aesthetics to the field of education. In that sense, this research aims to describe how aesthetic is conceived and discussed from different theories of the human sciences, considering its relationship with art and education. The qualitative approach is used, of a descriptive character and bibliographical nature. For the data analysis form, the interpretative research technique was adopted. The theoretical data were constructed over 3 years from an extensive bibliographic review carried out in articles and books about art and aesthetics. As results, the data revealed that aesthetics presents different conceptions in scientific historic, sometimes converging with the educational field, sometimes distancing itself from it. During the school or academic career, it may occur that the student does not want to make an object or activity just for producing, he may want to do it 
elaborate, and this responds to a practical need for material production that humans have. Being an expression of something well defined, coherent and well resolved, it can be understood as an expression of beauty, because it presents aesthetic quality.

KEYWORDS: art, aesthetics, education, humanities.

\section{INTRODUÇÃO}

Pesquisas relacionadas às concepções de estética e a sua relação com as artes vem sendo estudadas há bastante tempo na literatura científica. Contudo, são poucas ainda as revisões sistemáticas acerca da estética em consonância com as artes no campo educacional, e que considere outros objetos (e não necessariamente obras de artes) como sendo estéticos.

Ao abordar este tema, a partir de uma extensa pesquisa bibliográfica realizada em importantes matrizes filosóficas, sociológicas e educacionais, buscou-se contribuir para a produção de conhecimento na área, o que permite ampliar um pouco mais do que se entende por estética nas ciências humanas.

Este estudo faz parte de uma pesquisa de doutorado ${ }^{1}$ desenvolvida na Universidade Estadual Paulista Júlio de Mesquita Filho (UNESP), campus de Marília, Brasil, que pesquisou o letramento estético com estudantes jovens e adultos camponeses. Especificamente para este artigo, buscou-se resolver o seguinte problema: como a estética é concebida e discutida nas ciências humanas, tendo como foco a sua relação com a arte na educação?

A pesquisa seguiu a abordagem qualitativa, de caráter descritivo e de natureza bibliográfica (Bogdan y Biklen, 1994). Para a forma de análises dos dados, adotou-se a técnica da pesquisa interpretativa (Erickson, 1985). Os dados teóricos foram construídos a partir de extenso levantamento bibliográfico realizado em artigos e livros a respeito da arte e da estética na pesquisa em ciências humanas durante 3 anos, analisados à luz da literatura científica utilizada neste estudo.

Com os dados coletados e organizados nesta pesquisa, e considerando os objetivos e os procedimentos metodológicos deste estudo, desenvolveu-se cinco categorias, geradas nas análises do levantamento bibliográfico realizado no material pesquisado, descritas abaixo:

a) Dimensões da arte na educação.

b) Concepções e sentidos da estética.

c) A estética filosófica.

d) A estética sociológica marxista.

e) A estética na formação de professores.

Para apresentar este manuscrito, após essas considerações iniciais, analisa-se na sequência as concepções de estética a partir de importantes teorias filosóficas e sociológicas em diálogo com as artes na educação. Em seguida, apresenta-se algumas conclusões acerca desta investigação, bem como os principais resultados encontrados a partir da perspectiva interpretativa, além de indicativos para estudos futuros, que possibilitem ampliar um pouco mais o que se entende por estética nas ciências humanas.

\section{DIMENSO\#ES DA ARTE NA EDUCA\#A\#O}

Conceituar arte não é tarefa fácil, tampouco objetivo nesta pesquisa. Arte envolve uma multiplicidade de métodos e especificidades que, a princípio, torna impossível neste momento propor um único conceito. Diante disso e, na tentativa de auxiliar nessa questão na perspectiva educacional, Ferraz e Fusari (2010) esclarecem que o seu conceito precisa considerar o tempo histórico em que a obra ou objeto artístico foi produzido, para que seja possível ampliar o seu conceito e as pesquisas que possibilitem compreender o seu significado na vida humana, a partir da diversidade de manifestações artísticas surgidas ao longo da história da humanidade: 
A arte é uma das mais inquietantes e eloquentes produções do homem. Arte como técnica, lazer, derivativo existencial, processo intuitivo, genialidade, comunicação, expressão, são variantes do conhecimento artístico que fazem parte de nosso universo conceitual, estreitamente ligado ao sentimento de humanidade. (Ferraz y Fusari, 2010, p. 101)

Em concordância com as autoras, Araújo e Oliveira (2015) entendem que a arte tem importante papel na sociedade, pois é o meio pelo qual o indivíduo pode se comunicar com a realidade a sua volta, expressandoas de diferentes formas, o que permite dizer que a arte modifica a realidade. À vista disso, essa expressão do real carrega uma carga de experiências que o indivíduo construiu ao longo de sua vida e expressa pela arte. Ao conceber a realidade e materializá-la no objeto artístico, o indivíduo a transforma e se humaniza dialeticamente.

Arte é criação, fruto do trabalho humano; portanto, fenômeno social e cultural que possibilita ao estudante jovem e adulto interpretar a realidade por meio de objetos artísticos e estéticos. Como produto social, a arte se relaciona com as pessoas de diferentes realidades e experiências, ao produzir conhecimento significativo e qualitativo dessa realidade. Nessa diretriz, entende-se que a arte não deve ser analisada fora da totalidade humana, tampouco, desconexa do processo educativo.

Além disso, parte-se do pressuposto de que o estudante jovem ou adulto são sujeitos históricos que se constituem na relação social construída com os seus pares e na qual produzem trabalho. Nesse sentido, as experiências são parte singular de suas vivências acumuladas ao longo de suas vidas. Por meio da arte, o educando pode encontrar motivações para compreender melhor o processo histórico e social do qual faz parte, pois a arte é conhecimento e um saber estético que produz novas ideias. Portanto, o conhecimento artístico possibilita experiências significativas para ele, a partir do contato constante com a arte.

Dito com outras palavras, arte é criação essencialmente humana. É expressão, porém, não apenas a expressão de sentimentos do mundo, mas conhecimento e meio de representar a realidade. Está presente na sociedade desde a pré-história, na qual se pode encontrar um grande legado cultural e artístico nas pinturas rupestres em diferentes localidades do mundo, inclusive no Brasil. Ela desperta nas pessoas diferentes emoções, como menciona Vigotski (1998). Isto também está relacionado com as vivências em arte que o estudante tem, ao trazer para a sala de aula as suas experiências com a arte ao longo de sua vida.

Sob esse pensamento, Marx foi o primeiro a perceber a relação da arte com o trabalho, entendendo-a como criação humana. Contudo, para que essa relação fosse possível, foi necessário compreender, primeiramente, que a arte e o trabalho caminham juntos; portanto, não são lados diferentes da mesma moeda.

Para Marx e Engels (1974), tanto a arte quanto o trabalho são manifestações criadoras do homem, que se iniciaram ainda na pré-história, quando o homem libertou a mão para produzir trabalho, tanto por meio das ferramentas que utilizava para produzir seu sustento, quanto pelos desenhos que fazia nas paredes das cavernas. Segundo esses teóricos, foi a partir desse momento que foi possível produzir arte, pois "a natureza criadora do homem se encontra no trabalho, materializado na forma de objeto artístico” (p. 196).

Dito de outra maneira, a arte, por ser fruto do trabalho humano na história, forma de conhecimento e expressão do real, leva o indivíduo a ter consciência das transformações de sua realidade. Em vista disso, sendo um objeto estético que comunica ideias, anseios e conhecimentos não apenas individualmente, mas também coletivamente, possibilita ao indivíduo apreciar a vida e a experiência humana registrada no objeto/obra.

Pareyson $(1997 ; 1993)$ afirma que a relação entre arte e natureza é antiga, pois remonta desde a antiguidade grega. Se antes arte, nessa relação, era concebida como imitação da natureza, atualmente essa concepção, considerando as transformações que a arte sofreu ao longo dos séculos (arte como cópia fiel a realidade: fotografia; ou imagem deformada: abstração, por exemplo), parece estar mais relacionada à expressão de sentimentos e emoções do indivíduo. Além disso, faz uma importante observação: precisa-se de arte ${ }^{2}$ para fazer qualquer coisa. Ou seja, desde as técnicas mais simples às mais complexas, são necessárias criações, invenções, formações. Daí, o fazer com arte, pois durante sua formação há sempre a presença do caráter inventivo, criativo (característicos da arte). Ressalta que a arte está presente em toda a história e atividade 
humana, pois praticamente tudo que o indivíduo faz, tem arte, pelo simples fato de as atividades necessitarem de criações, invenções, para serem executadas ou desenvolvidas em diferentes funções e finalidades.

Em todo o campo de atuação humana tudo o que se faz de certo modo se faz inventando o como fazer. Precisa-se de arte para fazer qualquer coisa, e nada se pode fazer bem sem arte. Ou seja, a capacidade de inventar o modo de fazer fazendo, e de fazer sabendo fazer, e em nada se obtém um bom resultado se o fazer não se faz inventivo, além de produtivo, tentativo e figurativo, além de executivo e realizador. Daí resulta um imenso e inexaurível campo de pesquisa para a estética. (Pareyson, 1993, p. 64)

Numa abordagem teórica muito próxima da anterior, Duarte (1981) afirma que a arte na educação possibilita ao indivíduo dialogar com o mundo a sua volta, produzindo interpretaçóes significativas da realidade, o que possibilita ampliar seu campo de compreensão, de tal modo que por outro meio seria impossível. Logo, o indivíduo se comunica com a realidade por meio de signos verbais e não verbais, e tem na linguagem o principal mecanismo para essa compreensão. Destarte, a linguagem possibilita a esse indivíduo interpretar o mundo, dar sentido a ele, pois ela é fundamental para que ele possa pensar, raciocinar, sentir e agir no mundo. Esse sentido de humanização permite fazer a seguinte afirmação: "homem e cultura estão indissoluvelmente ligados: só há cultura através do homem, e o homem só existe pela cultura" (Duarte, 1981, p. 46).

A arte possibilita conhecer as experiências vividas e permite o encontro do indivíduo com o mundo (Duarte, 1981). Como destaca o autor, enquanto conhecimento, a arte é fundamental para que o indivíduo organize suas ações no mundo, pois o meio cultural e social não é apenas físico, mas simbólico também e, tem na arte, um meio relevante para orientar as ações desenvolvidas. Por isso, "ao encontrar símbolos que permitem visualizar (no sentido de objetivar) nossos sentimentos, sua compreensão torna-se mais fácil, e o conhecimento se estende a regiões inacessíveis ao pensamento discursivo" (Duarte, 1981, p. 94). Ou seja, o indivíduo se utiliza da linguagem para se situar no mundo e, nesse processo, se apropria da cultura.

Segundo Vigotski (1998), no campo da psicologia, não foi elaborada nenhuma teoria de arte que tenha sido concluída ou que contribuísse plenamente para a construção de uma psicologia da arte. Para ele, a maioria dos psicólogos apenas criticavam alguns problemas e questões de teorias da arte, de forma fragmentada, o que não ajudou, efetivamente, na elaboração dessa psicologia. Todavia, destaca que a psicologia considera a arte como conhecimento. Menciona que tanto a poesia quanto a arte são tipos específicos de pensamento, se assemelhando ao conhecimento científico, só que por diferentes caminhos, embora se diferencie deste pelo método.Consequentemente, afirma que, para formular uma teoria que possibilite compreender como ocorre o processo artístico, a obra de arte pode ser aplicada como qualidade, atributo a novos fenômenos ou ideias, igualmente como acontece na imagem da palavra que auxilia a identificar seu significado. No entanto, o autor esclarece que a forma não é trabalho do pensamento. É a partir da forma que se inicia a arte.

Como mostra o autor, a arte é uma forma ideológica que se diferencia das demais ideologias e é ligada ao campo psíquico humano. Dessa maneira, a arte se refere ao sentimento (entendido como um campo específico do psiquismo humano). Entende que "tudo que o artista encontra pronto, palavra, sons, fábulas correntes, imagens comuns, etc., tudo isso constitui o material da obra de arte, incluindo as ideias contidas na obra" (Vigotski, 1998, p. 60).

Nesse sentido, ao considerar a arte como criação humana, Vigotski (2009) compreende que o ato de criar é um tipo de atividade em que o indivíduo cria algo novo, original, independentemente se é algum objeto elaborado pela mente humana ou pelo mundo externo. Ou seja, do mesmo modo que defendia Marx, o autor concebe que essa atividade, possibilita ao indivíduo a construir seus próprios meios de existência. Nesse raciocínio, ressalta dois tipos de atividade humana: a ligada à memória - reconstituidora ou reprodutiva que se refere à reprodução de condutas aprendidas anteriormente por meio de uma ação, como, por exemplo, em desenhos de observação dos quais reproduzo algo que assimilei em minha mente numa dada época ou momento de minha vida.

A outra atividade é denominada de combinatória ou criadora, que diz respeito ao que não é real, isto é, algo que é fantasioso, que é imaginado no futuro, o qual o indivíduo não vivenciou nenhuma vez na realidade 
concreta. É como se a pessoa criasse uma imagem ou impressão que gostaria de viver ou conhecer no futuro. Embora essas atividades sejam discrepantes em seus significados, são semelhantes num ponto: ambas têm na imaginação o seu cerne catalisador da criação humana. A esse respeito, esclarece:

[...] a imaginação, base de toda atividade criadora, manifesta-se, sem dúvida, em todos os campos da vida cultural, tornando também possível à criação artística, a científica e a técnica. Nesse sentido, necessariamente, tudo o que nos cerca e foi feito pelas mãos do homem, todo mundo da cultura, diferentemente do mundo da natureza, tudo isso é produto da imaginação e da criação humana que nela se baseia. (Vigotski, 2009, p. 14)

Como demonstra o autor, a atividade criadora depende das experiências do indivíduo com o meio, pois essas são fundamentais para que as imaginações/fantasias possam ser construídas na mente humana. Assim, quanto mais experiências diversas o indivíduo tiver, mais condições terá de criar essas fantasias da realidade. Tanto a imaginação quanto a experiência são dependentes uma da outra, pois a primeira é fundamental para que a mente humana se desenvolva e, para se desenvolver, é importante que o indivíduo amplie a sua experiência a partir da interação cultural, inclusive, com as experiências de outrem.

Em adição, um aspecto interessante se mostra presente nessa relação: a emoção. Sobre isso, Vigotski (2009) destaca que ela pode se manifestar de duas formas: na primeira, o sentimento influi na imaginação (Lei do Signo Emocional Comum), se referindo ao sentimento que se representa por meio de imagens conhecidas dessa emoção. Ou seja, o indivíduo, dependendo do momento de sua vida, de alegria ou tristeza, percebe as coisas de formam diferentes; portanto, expressa sentimentos diferentes. Se a pessoa está com medo, ela expressa esse sentimento tanto externo (tremor das mãos, expressão pálida, alteração na respiração, etc.) quanto interno (seleciona ideias, imagens e impressões desse sentimento).

$\mathrm{Na}$ outra forma manifestada pela emoção, segundo o autor, a imaginação influi no sentimento. Essa forma é conhecida como Lei da Realidade dos Sentimentos ou da Sensação Real. Por ter elementos afetivos na imaginação, a imagem/fantasia criada pelo indivíduo, como, por exemplo, a sombra de um objeto que, ao refletir na parede, parece-lhe algo estranho, faz com que o indivíduo imagine que seja a sombra de outra pessoa lhe causando temor, medo. Por mais que essa imagem seja irreal, o sentimento de mero susto provocado por ela é real, devido às experiências que o indivíduo já vivenciou.

Nesse sentido, Vigotski (2009) ressalta que nessa forma de emoção o objeto artístico também exerce uma ação no indivíduo bastante forte, pelo fato de provocar nele diferentes emoções. $\mathrm{O}$ autor chama a atenção ao fato de que nessa relação entre realidade e fantasia essa última pode se tornar real, caso o indivíduo não a tenha vivido anteriormente e que se concretize na realidade. Assim, a imaginação passa a se tornar real.

Para concluir essa análise, Vigotski (2007) afirma que o uso de signos é fundamental para o desenvolvimento humano e na formação da consciência, uma vez que tanto as palavras quanto as imagens são linguagens que desenvolvem o pensamento; portanto, arte e leitura são qualidades e meios necessários para a comunicação e interação humanas.

No campo educacional, pelo fato da escrita ser um registro de mensagens verbais, que une um sistema de signos que envolve palavras, sons e símbolos (como nas histórias em quadrinhos, por exemplo, que envolve desenhos e textos), a relação entre a arte, estética e a leitura é ampliada: "a linguagem escrita converte-se num sistema de signos que simboliza diretamente as entidades reais e as relações entre elas" (Vigotski, 2007, p. 126).

Nessa perspectiva, a arte possibilita também uma compreensão elevada da realidade e das contradições presentes nela, pois, por ser criação humana, fruto do trabalho, produz interpretações significativas do real, importante para compreender a totalidade humana como processo histórico e social em constante transformação. Por isso, é importante as escolas brasileiras de Educação Básica possuir um currículo mais flexível, interdisciplinar, que considere a realidade do educando no processo educativo, importante para um desenvolvimento mais pleno do estudante. 
É possível dizer, portanto, que a arte amplia o conhecimento cultural do estudante e, para Vigotski (2009), o desenvolvimento do indivíduo está ligado diretamente à interação com a cultura e a sua apropriação. Com efeito, possibilita o desenvolvimento das funções psicológicas superiores.

Para elucidar um pouco mais esse pensamento a respeito da arte e da estética na educação escolar, Barbosa (1998) chama a atenção para que os estudos voltados a essas categorias não fiquem relacionados apenas às teorias sobre beleza, mas também sejam relacionados com o apreciador da arte, tendo na experiência estética a base dessas discussões. Desse modo, defende que o professor deve ser um conhecedor da estética para que esteja preparado para possíveis questionamentos que, por ventura, possam surgir de seus alunos, visto que "a estética tem um enorme potencial esclarecedor e estimulador do questionamento reflexivo” (Barbosa, 1998, p. 41). Ou seja, na educação, a estética deve estar relacionada à leitura da arte, auxiliando o estudante a tomar decisões e a emitir juízos de valor, o que de fato, ampliará a sua experiência com a arte:

A arte na educação como expressão pessoal e como cultura é um importante instrumento para a identificação cultural e o desenvolvimento individual. Por meio da arte é possível desenvolver a percepção e a imaginação, apreender a realidade do meio ambiente, desenvolver a capacidade crítica, permitindo ao indivíduo analisar a realidade percebida e desenvolver a criatividade de maneira a mudar a realidade que foi analisada. (Barbosa, 2008, p. 18)

Da mesma maneira, Iavelberg (2003) menciona que é importante o professor trazer conteúdos de arte a partir do cotidiano dos alunos, importante para despertar o interesse pelas aulas. Segundo a autora, essa prática valoriza a cultura individual e coletiva, ao criar no aluno um sentimento de orgulho da própria cultura da qual foi criado e aprender a respeitar e a conhecer a diversidade cultural de outros povos. Nesse aspecto, assevera que considerar os conhecimentos prévios dos alunos é relevante para que o docente possa mediar nesses o conhecimento produzido sobre a arte e a estimular neles a produção de pesquisas sobre o tema, para que possam avançar na aprendizagem.

Barbosa (2012) salienta que a arte e a história são fundamentais para que o indivíduo tenha consciência de identidade nacional, mas, para isso, tem na escola o principal lugar para ter acesso a esse conhecimento que, inclusive, poderá contribuir para a formação estética do educando, ao ter acesso a diferentes manifestações artísticas e culturais de diferentes lugares, ampliando seu conhecimento de mundo.

Arte não é apenas básica, mas fundamental na educação de um país que se desenvolve. A arte não é enfeite. Arte é cognição, é profissão, é uma forma diferente da palavra para interpretar o mundo, a realidade, o imaginário, e é conteúdo. (Barbosa, 2012, p. 04)

Na esteira dessa reflexão, Hernández (2000), baseando-se em Vigotski (2007), frisa que a aprendizagem por meio da arte exige um pensamento superior, pois envolve análises, planejamentos, resoluções de problemas e meios de compreensão e interpretação, além de conclusões desenvolvidas pelo indivíduo. Logo, o desenvolvimento por meio desse tipo de atividade leva o estudante a ampliar a sua habilidade manual, a aguçar seus sentidos e aumentar o seu conhecimento sobre determinado objeto artístico. Além disso, pode proporcionar ao estudante um fortalecimento de sua identidade "em relação às capacidades de discernir, valorizar, interpretar, compreender, representar, imaginar, etc.” (p. 42). Com efeito, a arte é importante para a compreensão da cultura visual, pois possibilita entender como as diferentes representações visuais se desenvolveram no percurso histórico da sociedade e como se constituem na contemporaneidade (Hernández, 2000).

Para seguir no andamento dessas reflexões, Bertoloto, Campos e Monteiro (2017) compreendem que a arte é fundamental para a formação estética e intelectual do indivíduo, pois amplia o entendimento da realidade a sua volta. Por conseguinte, ao ter contato com as diferentes manifestações artísticas, a imaginação do indivíduo começa a fluir, o que é fundamental para que sua criatividade se desenvolva. Consequentemente, é possível dizer que a arte proporciona uma formação plena no educando.

Com essa perspectiva, considerar por meio da arte as vivências do estudante jovem ou adulto no processo educacional possibilita entender melhor a sua concepção de mundo, os seus interesses e necessidades, aspectos 
fundamentais para o seu desenvolvimento e processo de humanização. Assim, a escola precisa oferecer ao estudante meios para que ele se desenvolva e se aproprie de conteúdos culturais da sociedade e da sua realidade, principalmente. Com efeito, a apropriação cultural permite a ele ampliar o seu entendimento da realidade, além de proporciona-lhe os meios para atuar de forma mais crítica nas questões que envolvem os seus direitos e lutar por eles. Desse modo, se tornará mais participativo nas decisões que precisará tomar nas comunidades em que vive, bem como no debate acerca de temas relevantes em seu meio social.

\section{1 . CONCEPÇÕES E SENTIDOS DA ESTÉTICA}

Etimologicamente, Estética é um termo originado "do grego clássico aisthesis, referindo-se a conhecimento sensível, através dos sentidos, das sensações” (Martins, 2011, p. 312). Em concordância com Martins (2011), Pontes (2013) esclarece que o termo estética - aisthetique - embora tenha surgido do termo aisthesis, não se referia, a princípio, à arte, apenas ao sensível.

Embora tenha raízes fortemente marcadas pela filosofia ${ }^{3}$, ligada à concepção de belo nas artes, ao longo da história da humanidade essa ciência passou por inúmeras transformações, fazendo com que o seu conceito se ampliasse, principalmente na contemporaneidade. E isso foi devido a um fator principal: a arte já não é mais lida e apreciada dentro de cânones como ocorria séculos atrás. Ao romper com os padrões estéticos voltados a um ideal de belo, a arte possibilita ao indivíduo retratar a sociedade por diferentes meios, expor a sua subjetividade e conhecimento sem se preocupar com tais padrões, o que lhe possibilita tomar consciência da própria realidade e a superá-la. Nessa perspectiva, Martins (2011) ressalta que essa é uma nova forma do indivíduo propor o seu modo de estar e viver no mundo.

Segundo Pontes (2013), a palavra estética comporta uma diversidade de significados que foram sendo construídos em diferentes épocas da história da humanidade, principalmente a partir da antiguidade grega. Em alguns desses momentos, estética estava relacionada à filosofia da arte, em outros à teoria do belo e, em alguns, associada a teorias da arte. Porém, ressalta que, quando relacionada à experiência estética, outros significados são produzidos nessa ciência. Esclarece ainda que vinculada ao conhecimento sensível é relevante, pois a maioria das experiências estéticas só foi possível por meio desse conhecimento.

Nessas considerações, Pontes (2013) destaca que foi apenas no século XVIII que foram sistematizadas as preocupações por critérios racionais na sociedade, ao entender o indivíduo não apenas como ser pensante, mas também sensível e racional. Diante disso, a Filosofia, preocupada com essas questões, se debruçou na sensibilidade, o que culminou na designação da estética como ciência, muito devido aos estudos do filósofo alemão Alexander Gottlieb Baumgarten (1714-1767).

Ao refletir sobre essa época, Pontes (2013) enfatiza que anteriormente ao século XVIII a arte e o belo não faziam parte do bojo filosófico, pois a primeira se referia à arte ao fazer artístico - arte enquanto técnica, enquanto a segunda remetia ao bem, à verdade, ao perfeito, termos postulados pela metafísica.

Com o propósito de tentar enriquecer o debate acerca da estética, Vázquez (2005) esclarece que essa categoria é um ramo do conhecimento científico ${ }^{4}$ que precisa ser melhor investigado. Salienta que qualquer objeto ao qual se atribui alguma qualidade específica pode fazer parte do universo estético, como, por exemplo, uma paisagem, uma flor entre outros, além daqueles produzidos pelo homem, como uma mesa, uma escultura e, inclusive, um texto escrito. Destaca que, por mais que façam parte de um mesmo universo, possuem diferentes funções, características e aparências visuais. É por isso que a estética se mostra relevante, pois enquanto ciência proporciona estudar essa diversidade de objetos, a partir do desenvolvimento do pensamento.

Com esse raciocínio, destaca-se a fala de Duarte (1981) ao dizer que:

É comum ouvir-se, especialmente entre os profissionais da medicina e da psicologia, a seguinte assertiva: 'estou atendendo (ou tratando de) um caso muito bonito’. Ora, será que beleza a que se refere o profissional se encontra em um corpo (ou 
mente) enfermo? Não. A beleza, aí, reside na relação que ele mantém com um fenômeno que deve ser decifrado. Ela consiste no prazer experimentado por ele ao vencer um desafio imposto pela doença: compreendê-la e atuar sobre ela de forma correta. Sob todo o seu equipamento e raciocínio lógico e científico, subjaz um sentimento da situação que ele interpreta como belo. (Duarte, 1981, p. 31-32)

Como mostra o autor, a qualidade estética é fundamental para compreender a beleza de um objeto, pois o fundamental é entendê-lo em sua essência e enquanto boa forma, bem resolvido. O sensível aqui demonstrado está diretamente relacionado à experiência de vida do indivíduo com a realidade da qual faz parte. Ademais, as emoções se fazem presentes ao tocar o indivíduo na relação estética entre ele e o fenômeno ocorrido, ao conectar a aparência e a essência desse fenômeno.

Nesse raciocínio, Pareyson (1997) salienta que a arte, como necessária à vida humana, pode ser encontrada não apenas nos objetos físicos, mas no pensamento, na ação humana. Assim, sendo obras bem feitas, isto é, bem sucedidas, podem sim ter um caráter e qualidade estética. Portanto, são verdadeiras, boas, melhoradas.

Para tanto, a respeito dos objetos produzidos sem finalidade estética, mas que funcionam esteticamente, Vázquez (1999) assevera que a relação entre esses objetos e o indivíduo ocorre de forma sensível. Contudo, na visão do autor, o indivíduo precisa ter uma consciência (estética) desse objeto, para que ele possa transformálo. Ou seja, mesmo não tendo sido elaborado para fins estéticos, mas se há consciência para elaborá-lo, se há uma capacidade do indivíduo de criar esse objeto, se tem essa sensibilização, e se os traços da forma do objeto são precisos, perfeitos, dinâmicos, pode ser considerado um objeto de relação estética.

Vázquez (1999) leva a compreender que a experiência estética e a produção artística são formas de desenvolvimento humano situadas num dado contexto histórico e social. É por isso que a estética produz conhecimento e dialoga com diferentes áreas do conhecimento para que se possa enriquecer de outros aportes teóricos no desenvolvimento de suas teorias. Nessa perspectiva, tanto a estética quanto a arte nutrem de teorias históricas que têm como objetos a sociedade e o homem, o abstrato e o concreto, importante para situá-las historicamente na pesquisa em ciências humanas.

Como toda ciência, a estética pretende descrever e explicar seu objeto próprio: certa relação com o mundo, assim como
a práxis artística em cujo produtor se objetiva essa relação. Ocupa-se, pois, de certos fatos, processos, atos ou objetos que
só existem pelo e para o homem, e que justamente por isso se consideram valiosos ou portadores de um poder especial: o
estético. Por essa dimensão axiológica de seu objeto, a estética se distingue das ciências naturais, embora sua atenção possa
coincidir com elas em um mesmo objeto: a natureza. Mas o belo natural que interessa à estética não é o natural que existe
em si antes ou independentemente do homem, justamente o que interessa às ciências naturais, mas sim a natureza que se
constitui esteticamente por ele. (Vázquez, 1999, p. 53)

Com esse fragmento, o autor deixa claro que o objetivo da estética é o ser humano, o social, aquilo que tem um valor ou qualidade estética, e que se desenvolve no percurso histórico da humanidade. Por isso, entendese estética na contemporaneidade não como normativa, isto é, regida por determinadas regras ou padrões, mas uma ciência que tem a missão de "descrever e explicar seu objeto peculiar, humano ou humanizado, sem restringir nele o que tem de valioso. E para isso recorre, como toda ciência, à construção do objeto teórico correspondente" (Vázquez, 1999, p. 54), ao transformar a realidade e nela ser transformada, numa relação dialética. Com efeito, não há um belo ideal, segundo o posicionamento do autor. Mas há o belo que se desenvolve historicamente na sociedade:

[...] chamaremos belo a um objeto que, por sua estrutura formal, graças a qual se inscreve certo significado, produz um prazer equilibrado ou um gozo harmonioso. Portanto, como certo prazer ou gozo acompanham sempre toda experiência estética, e não só a do belo, nossa resposta não faz senão introduzir o matiz de uma maior serenidade ou um maior equilíbrio emocional no efeito prazeroso ou contemplação gratificante de todo o estético. (Vázquez, 1999, p. 204)

Para encaminhar o debate sobre estética aqui desenvolvida, Osborne (1968) ressalta que se algo foi feito para funcionar bem, se a sua elaboração atendeu bem a tarefa para a qual deveria executar, então esse algo será belo. Essa intencionalidade, na visão do autor, não necessariamente está relacionada à aparência física, pois esse prazer sentido e recebido pelo indivíduo é "semelhante ao que nos dá um problema preciso de xadrez ou 
uma elegante demonstração matemática" (p. 44). Nesse sentido, entende-se que se essa intenção se adéqua a um propósito pretendido; portanto, garante-se a beleza visual. Contudo, o simples fato de se adequar a uma condição não é garantia dessa beleza, o que vai ocasionar uma "antítese entre a beleza visual e a beleza intelectualmente apreensível” (p. 44). Assim, algo pode ser belo a uma intenção/finalidade e não belo a outra intenção/finalidade.

Logo, a beleza não residiria apenas nos objetos, no indivíduo ou na realidade que o circunda, mas no encontro entre "o homem e o mundo, entre a consciência e o objeto (estético). A beleza habita a relação" (Duarte, 1981, p. 85). Em outras palavras: "o feio pode integrar a arte com o mesmo fundamento que a integra o belo. $\mathrm{O}$ objeto descrito e reproduzido numa obra de arte pode, por si mesmo, estar fora dessa obra, ser feio ou belo" (Vigotski, 1998, p. 296).

Todavia, Vázquez (1999) reforça a discussão sobre a necessidade de se ampliar o conceito de estética: não deve ter conceitos fechados, apenas se referindo à arte, ao belo, pois pelo fato de estar presente na história da humanidade e, considerando que essa está em constante transformação, seus conceitos merecem ser ampliados e compreendidos num sentido aberto, para que seus fenômenos não fiquem limitados ou passem despercebidos quando descritos, analisados e explicados.

É importante ressaltar que essa crítica feita aos conceitos clássicos e tradicionais por Vázquez (1999) não exclui aquilo que já foi amplamente estudado sobre a estética no percurso da humanidade (em particular, o sensível), mas deve considerar novas relações estéticas com a realidade. Nesse pensamento, o concreto da realidade entendido aqui é teórico e não uma mera reprodução do real. Com efeito, a estética não tem uma explicação estética, mas abstrata, conceitual.

O objeto de estudo da estética que compreende a tríade humano-social-histórico enfatizado por Vázquez (1999) não é elaborado de forma imediata ao conhecimento. É preciso, primeiramente, construir conceitos que constituem o objeto teórico, para que ele possa ser descrito e explicado na realidade. Com essa ideia, Marx o denominará de concreto pensado, isto é, o objeto que só existe no pensamento, portanto, na abstração. Dessa maneira, o objeto vai sendo teoricamente criado, enquanto que o concreto real é aquele objeto que não depende do primeiro, por existir efetivamente na realidade:

Portanto, embora os conceitos ou teorias acerca deles só existam como produto da atividade cognoscitiva - que consiste, segundo Marx, na ascensão do abstrato ao concreto, entendido como reprodução ascensional do "concreto real" pelo "concreto abstrato" - definitivamente o objeto teórico só existe por e para o objeto real; ou seja, como meio ou instrumento para conhecê-lo [...] O que reproduz, pois, passando de uma abstração a outra, é o objeto real. Em consequência, o conhecimento que a estética persegue, como o que buscam outras ciências, há de consistir na produção do objeto teórico (conceitos, leis, teorias) que permita a reprodução abstrata, conceitual do concreto. (Pareyson, 1993, p. 62)

Compreende-se, a partir do excerto acima, que os conceitos desenvolvidos acerca da estética no percurso histórico da humanidade estão diretamente relacionados ao seu desenvolvimento histórico, social e cultural. Ao citar Marx, o autor deixa claro que os conceitos construídos precisam ir do abstrato ao concreto, isto é, devem promover o pensamento teórico.

Nesse caminho desenvolvido, Vigotski (1998) afirma que há dois campos da estética: a estética de cima (especulativa, base sociológica e histórica; materialismo histórico) e estética de baixo (empírica e positiva). Compreende a estética como uma teoria do comportamento estético, que envolve tanto o prazer estético quanto a criação artística. Destaca ainda que esta base sociológica não nega o psiquismo do homem social nem evita de estudá-lo como instrumento mediador nas relações econômicas e sociais que criam diferentes ideologias, mas ressalta a necessidade de estudar o psiquismo, devido ao fato das relações econômicas e a ideologia se distanciarem cada vez mais, e a arte não conseguir ser mais explicada apenas a partir dessas relações econômicas. Desse modo, "se está reconhecendo que a arte, no mais aproximado sentido, é determinada e condicionada pelo psiquismo do homem social” (Vigotski, 1998, p. 11).

Sob essas reflexões, Vigotski (1998) menciona as emoções estéticas causadas pela obra de arte, importantes para compreender como a obra provoca no indivíduo diferentes sensações e sentimentos. Aborda que essa 
emoção ainda é incompreensível ao indivíduo, o que oportuniza afirmar que são necessários mais estudos sobre essa temática. Sobre isso, reforça que para estudar com afinco os sentimentos que uma obra de arte causa no indivíduo é necessário estudá-los por meio de uma psicologia especial.

Nesse sentido, Vigotski (1998) compreende que as emoções assumem importante papel durante o processo artístico, sendo de diferentes tipos, como, por exemplo, de tristeza, alegria, indignação entre outros. No entanto, ressalta que a emoção lírica da obra possibilita também que o indivíduo se emocione (ou por palavras na poesia, num verso, ou na própria obra visual/plástica mesmo). A esse respeito, Vigotski (1998) salienta que a emoção da forma é fundamental para a expressão artística, ao destacar as artes emocionais (arquitetura, lírica e música) e as artes intelectuais (artes plásticas).

A análise de Vigotski (1998) a respeito da reação estética conduz a dizer que toda reação pode ser expressa da seguinte forma: “o objeto estético é constituído de diversos componentes, que em si, são inteiramente diversos, mas tem em comum o fato de a cada elemento corresponder um determinado tom emocional" (Vigotski, 1998, p. 259), isto é, a forma do objeto faz parte da própria obra de arte a partir dos elementos emocionais que o próprio objeto traz. Noutras palavras, a obra de arte ou o objeto artístico pode tocar o indivíduo de tal forma que afete seus sentidos e, consequentemente, produz nele emoções como resposta a essa reação estética.

Sobre o conteúdo da arte, o autor esclarece que o sentimento debatido na arte é antigo. Há aqueles que falam que a arte apenas exprime sentimentos; outros que os sentimentos são apenas uma das expressões subjetivas do homem na produção artística. Ou seja, há vários tipos de concepções a respeito dessa categoria: alguns já existem e há outros que surgiram devido a experiências do indivíduo com o seu meio social e cultural. Há outros também que surgem durante o processo criativo e, por fim, há os sentimentos que aparecem após a obra estar concretizada.

Nesse sentido, é possível inferir que a arte possibilita não apenas expressar os sentimentos, mas vai além disso: leva o indivíduo criar e recriar a realidade, propor novas ideias e conhecimentos, dialogar com o mundo a sua volta, enfim, se comunicar a partir de um trabalho estético.

Porém, Barbosa (2008) chama a atenção ao fato de que, embora esteja diretamente ligada à expressão dos sentimentos, do sensível, a arte não deve ser considerada apenas isso, pois não se exploraria toda a sua gama de conhecimentos. Além disso, destaca que a arte contribui relevantemente para o desenvolvimento cultural de uma nação e, consequentemente, para a formação estética do indivíduo.

Ao defender que há arte em toda a atividade humana, Pareyson (1997) ressalta que:

[...] sem 'formatividade', nenhuma atividade é bem sucedida no seu intento. Em toda obra humana está presente um lado inventivo e inovador como primeira condição de toda realização. Isso explica como pode haver arte em toda atividade humana, ou melhor, como há a arte de toda atividade humana, no sentido de que, em qualquer circunstância, trata-se de fazer com arte [...] é necessário arte para fazer qualquer coisa: sempre e em qualquer circunstância, trata-se de 'fazer com arte'. (Pareyson, 1997, p. 31)

Ou seja, basta que a atividade prática, neste caso, o exercício, tenha forma, seja inventado; portanto, cria uma nova forma de fazer.

Essas reflexões conduzem a afirmar que a arte está totalmente ligada à vida humana. Mesmo assumindo diferentes funções e concepções ao longo dos séculos, ela se faz presente na civilização por diferentes meios. É razão de vida para quem a faz e a contempla, para quem penetra nela, isto é, "pode exercitar na vida uma grande função: educadora, ou moral, ou científica, ou religiosa, ou política, ou social” (Pareyson, 1997, p. 41).

Nesse ponto é possível associar a estética com a formação humana, no sentido de auxiliar o indivíduo a "desenvolver sentidos e significados que orientem a sua ação no mundo" (Duarte, 1981, p. 15). Ou seja, sendo um processo formativo, tem na sua forma o seu estado final e conclusivo da arte (Pareyson, 1997, p. 55). A educação tem nesse processo um dos seus principais elementos: a criatividade, que possibilita ao indivíduo criar significados, ideias, conceitos e interpretações dos objetos e mundo a sua volta. 
Nesse âmbito, a cultura se mostra presente e com papel fundamental na formação do homem, pois é no âmbito cultural que o indivíduo compreende o papel formativo da educação e se desenvolve. É nesse sentido que a arte também se mostra necessária na educação, pois tem na criação o seu cerne. Por meio da arte também se conhece a cultura de outros povos. Isto posto, é possível afirmar, portanto, que a arte e a educação estão diretamente relacionadas, pois ambas possibilitam a construção de significados, importantes para a formação estética do estudante.

Essa afirmação permite pensar numa dimensão estética da educação, ao compreender que a estética supõe harmonia e equilíbrio entre os elementos de determinada composição verbal e não verbal, como, por exemplo, a arte das histórias em quadrinhos, de imagens presentes em textos, ao proporcionar ao estudante criar novos sentidos para a sua vida no meio social em que está inserido, modificando a sua realidade e tomando consciência dela, "de modo que haja coerência, harmonia, entre o sentir, o pensar e o fazer" (Duarte, 1981, p. 16).

Outro aspecto que se entende ser importante nesse debate se relaciona à formatividade. Ela é ressaltada por Pareyson (1993) ao descrever que o próprio conhecimento é formativo, pois ele se forma a partir de conceitos, imagens e ideias. A respeito dessas imagens, espera-se, segundo o autor, que saiam perfeitas, que captem o melhor da coisa ou objeto, ou da representação de tal objeto. Para o autor, esse processo possibilita o surgimento do belo natural, pois "as coisas são belas enquanto vistas como formas, e para chegar a isso é preciso saber interpretá-las, penetrá-las e representá-las segundo uma imagem reveladora” (Pareyson, 1993, p. 14). Então, toda operação humana é formativa. Logo, o pensamento humano é formativo:

[...] ao se colocar e resolver um problema, ao deduzir de um princípio as consequências, ao efetuar uma demonstração qualquer, ao encadear raciocínios em um todo sistemático, é preciso realizar e executar movimentos de pensamento, e com o ato de invenção descobrir aqueles que a razão impõe no caso determinado, e formular expressamente os pensamentos. Tanto o pensamento quanto a ação, portanto, exigem força produtiva e capacidade inventiva, pois as operações especulativas e práticas são constituídas por uma atividade formativa que no campo específico executa e produz as obras ao mesmo tempo em que inventa o modo como se devem fazer. (Pareyson, 1993, p. 25)

Em consonância com esse processo formativo, o conhecimento humano pela arte tem um caráter interpretativo. Proporciona ao indivíduo, por meio de ações e interações com o meio, captar a realidade das coisas a sua volta, formando a imagem mental (figurativa) dessa realidade (Pareyson, 1993). A esse respeito, o autor compreende que essa formatividade se refere, portanto, à invenção, à criação, que pode ser pesquisada ao longo da vida humana, isto é, perpassa por inúmeras experiências que o indivíduo tem em sua vida, desde as mais simples como aprender a usar uma colher para se alimentar, as mais complexas como efetuar operações mentais.

Nesse trajeto construído, Pareyson (1993) ressalta que o processo de interpretação é infinito, pois o indivíduo, não satisfeito com a sua interpretação e buscando ampliar sua visão a respeito de determinado objeto ou conhecimento da realidade, buscará novos modos de interpretar, que podem implicar em novos meios de substituir, corrigir, analisar, negar ou confirmar a sua primeira interpretação. Isto é, o indivíduo "adota novos modos de ver, que lhe pareçam mais adequados a revelar a forma tal qual ela é, e não apenas como parecer, e assim [...] amplia e aperfeiçoa a sua primeira interpretação" (Pareyson, 1993, p. 180). Dito de outra forma, é preciso levar em consideração a essência e não a aparência da realidade.

Contudo, Pareyson $(1993 ; 1997)$ se aproxima novamente de Vigotski ao falar sobre boas práticas no ensino, que possibilitam um avanço no conhecimento. Ressalta que formar leva às tentativas de encontrar entre elas o êxito, ao sucesso escolar/acadêmico. Em adição a essa afirmação, destaca ainda que, independente da atividade a ser exercida, sempre implica um processo de produção, de criação; portanto, de formação intelectual.

Com essa reflexão construída, compreende-se que formar se refere ao ato de fazer e de saber fazer. Formatividade é aquilo que é bem feito, que teve um êxito, alcançou os objetivos propostos, mas sem seguir padrões ou regras pré-determinadas. 
Pareyson (1993) deixa clara a diferença entre estética da formatividade de forma. Para ele, o termo forma assume diferentes significados, sendo, portanto, ambíguo. Por isso, defende estética da formatividade. Segundo o autor, a forma entendida aqui se refere a um corpo organizado, que apresenta reciprocidade entre suas partes. Destarte, "em primeiro lugar, há a ideação de uma imagem interior, já toda acabada e formada, e depois a realização desta figura numa matéria física” (Pareyson, 1997, p. 186).

Ao ampliar a concepção de estética e, consequentemente, da arte presente em toda a atividade humana, esta pesquisa entende que a estética não existe sem a arte. Ou seja, a atividade humana tem um caráter criador, artístico; portanto, nos exercícios da atividade humana é possível encontrar sua formatividade, ampliando o conceito da própria arte.

Por último, mas não menos importante, menciona-se nesta pesquisa outro teórico relevante que traz apontamentos sobre a estética, que semelhante aos demais citados neste artigo, auxiliou a construir algumas reflexões nesta pesquisa. O artigo refere-se ao filósofo russo Mikhail Bakhtin (1895-1975). É preciso considerar a contribuição desse teórico nessa discussão a respeito da estética, não tem como excluí-lo disso. Em sua obra Estética da Criação Verbal (2011), deixa clara a sua insatisfação com a estética materialista dos formalistas russos de sua época, por considerá-los positivistas e esses não levarem em consideração em seus estudos a filosofia, o conteúdo e a forma, elementos fundamentais para a pesquisa em estética.

Nesse percurso, o autor tenta descrever a estética a qual defende: uma estética romântica e que considerasse a exterioridade em sua totalidade. Isto é, a vida só tem sentido se for algo visto do exterior, em outra pessoa, o que se torna indispensável para o pensamento estético. A esse fenômeno, Bakhtin denominou de exotopia.

Ao refletir sobre o personagem, Bakhtin (2011) traz algumas reflexões que podem auxiliar a compreender a discussão proposta neste manuscrito. Contribui ao afirmar que, ao elaborar o personagem, ele pode trazer elementos no seu próprio desenho que se refiram a sua vida, pensamentos e outras características pessoais. Dessa maneira, ao se relacionar e responder as inquietudes e questionamentos desse personagem na história, essas respostas, por serem exteriores ao autor, portanto, ao abordar a totalidade do personagem, passam a ter um sentido estético, pois apresentam uma característica criadora e produtora de sentidos. Portanto, "essa resposta reúne todas as afirmações e avaliações ético-cognitivas e lhes dá acabamento em um todo concretoconceitual singular e único" (p. 4). Ou seja, o autor cria e vê sua criação no objeto que ele está formando.

Em vista disso, destaca que não há acontecimento estético ${ }^{5}$ com apenas um participante, pois são necessárias duas consciências que, embora não se coincidam, são fundamentais para que esse processo ocorra. A esse respeito, frisa que esse acontecimento culmina na contemplação estética, ao dizer que ao contemplar no todo a outra pessoa diante de mim, observarei e saberei coisas que essa outra pessoa não pode ver segundo sua posição fora e diante de mim, como, por exemplo, o rosto e sua expressão - o mundo e suas coisas a sua volta.

O acontecimento estético não se fecha no âmbito de uma obra de arte; no trabalho sobre o autor e a personagem é essencial essa ampla concepção da atividade estética, bem como a ênfase sobre a sua índole axiológica. A personagem e seu mundo constituem o 'centro axiológico' da atividade estética. (Bakhtin, 2011, p. 424)

A relação de reciprocidade entre mim e o indivíduo permite que eu veja e saiba coisas que são inacessíveis a ele e acessíveis a mim. Bakhtin esclarece que esse excedente da minha visão é baseado pela singularidade da minha experiência e lugar no mundo. Em adição, afirma que essas ações completam o outro naquilo que ele não pode ver; contemplar-se. Portanto, pode ser considerada uma ação puramente estética.

Essa construção epistemológica permite dizer que é como se eu vivenciasse o indivíduo esteticamente que, para Bakhtin, se refere à compenetração: eu devo vivenciar o sujeito e me colocar no lugar dele, deve haver uma empatia entre mim e o outro. Segundo o autor, é fundamental que eu parta de minhas experiências em consonância com o mundo e com o objeto, isto é, que eu me dirija a um sentido adiante de mim. O objeto pode ser eu mesmo ou o todo do outro indivíduo. Desse modo, o valor estético - ato de criação - se realiza no momento em que o indivíduo vivencia o objeto de dentro próprio, isto é, no interior do objeto. Logo, o objeto estético se torna uma vida estética ao criar um personagem que se refira à totalidade da obra. 
A partir dessa tese, Bakhtin (2011) descreve como seria a abordagem estética e atividade estética:

\begin{abstract}
Quando tenho a minha frente uma figura simples, uma cor ou a combinação de duas cores, um rochedo real ou uma ressaca do mar na praia, e tento encontrar para eles uma abordagem estética, devo, antes de mais nada [...] humanizá-los; desse modo, viabiliza-se pela primeira vez a sua abordagem estética, realiza-se a condição básica de uma visão estética, mas a atividade estética empenhada ainda não começou, uma vez que permaneço no estágio do simples vivenciamento empático com a imagem animizada [...] Devo pintar um quadro ou escrever um poema, construir um mito, ao menos na imaginação, no qual o referido fenômeno seja o herói de um acontecimento acabado em torno dele ou um empecilho, mas isso é impossível se permaneço no interior de dada imagem [...] o quadro ou o poema que criei se constituirá em um todo artístico onde estará presente o conjunto de elementos estéticos indispensáveis. Sua análise será produtiva. A imagem externa do rochedo representado não vai somente exprimir-lhe a alma, como também concluir essa alma com valores transgredientes ao seu possível autovivenciamento; ela receberá o bem estar estético. (Bakhtin, 2011, p. 61)
\end{abstract}

Embora seja uma citação extensa, é esclarecedora. Bakhtin (2011) deixa explícito que a forma material que determina o tipo de arte que é (desenho ou pintura, por exemplo) também determina, mas de forma substancial, a estrutura do objeto estético. É na obra verbalizada do objeto que a arte se mostra mais concreta. Essa criação verbalizada não se refere à forma espacial externa (como no desenho e na pintura), pois seu material é a palavra, isto é, a forma espacial sua é a disposição do texto (capítulos, figuras, parágrafos, etc.). Assim, Bakhtin (2011) conclui ao afirmar que o objeto estético, embora se constitua também de linguagem verbal, não possui apenas palavras, o que permite, novamente, ampliar o conceito dessa categoria na pesquisa em ciências humanas.

É fundamental considerar nesse momento outro elemento significativo no pensamento de Bakhtin (1981, 2002, 2011). O autor considera que os elementos presentes na obra artística (objetos, a descrição do ambiente, costumes, natureza etc.) constituem a paisagem verbalizada da obra. Reforça que tais elementos que são representados na obra devem manter uma relação estética com o indivíduo.

Por conseguinte, Haynes (2002) destaca em obra não traduzida para o português Bakhtin and the visual arts que a filosofia da linguagem desenvolvida por Bakhtin contribuiu para a estética, o que implicou em novas problemáticas para o campo das Artes Visuais. Menciona que, embora não tenha deixado uma definição clara de estética, refutou concepções herdadas da estética kantiana e formalista. Considerava a estética como processo criativo e relacionado à vida. Bakhtin estava mais preocupado na forma como os indivíduos desenvolvem sua experiência, isto é, "como eles percebem um objeto, texto ou outra pessoa, e como eles moldam essa percepção em um todo sintetizado” (Haynes, 2002, p. 293, tradução minha). ${ }^{6}$

Para Haynes (2002), Bakhtin não se concentrou no conceito de beleza, mas em descrever o processo de como o indivíduo cria e se relaciona com o outro e com a vida. Nesse processo, pontua os textos e a arte como os principais elementos nesse processo. Com essa análise, observa que:

[...] a abordagem de Bakhtin à estética é, portanto, única. Baseia-se não apenas em categorias como a estética (a atividade estética ou o objeto estético) ou valores estéticos (verdade, bondade ou beleza), mas também na fenomenologia das relações do eu com o outro, relações que são incorporadas em corpos reais, no espaço e no tempo. (p. 294, tradução minha) ${ }^{7}$

O processo criativo sempre está aberto a mudanças e transformações. Essa afirmação é mencionada por Bakhtin e destacada por Haynes (2002). Importa destacar, entretanto, que os indivíduos se envolvem em atividades estéticas para desenvolverem as suas percepções e experiências. Essas atividades criativas são denominadas por Bakhtin de autoria, que envolve não apenas a autoria em textos, mas a relação do indivíduo com outras pessoas e com a vida.

Essa relação do eu com o outro presente nos estudos de Bakhtin foi expressa primeiramente com o conceito do ato responsivo. A partir desse momento, tanto a arte quanto a criatividade estão sempre relacionadas à vida. Desse modo, o indivíduo, enquanto ser responsável por seus atos, tem na vida e nas experiências vividas por ele a base de sua criatividade. Assim, Bakhtin afirma que o indivíduo não existe sozinho, como consciência isolada, pois seu trabalho criativo sempre está relacionado ao outro. 
Haynes (2002) assevera ainda que, nessa perspectiva bakhtiniana, a arte expressa uma relação dialógica e responsável com o indivíduo e com a realidade. Portanto, Bakhtin compreende que a arte deve existir em uma relação plena com a vida e na interação com o outro, pois só assim a criatividade se torna potencial no desenvolvimento das experiências do indivíduo com o mundo.

Outra perspectiva da estética que merece ser destaca nesta pesquisa e que entende-se ser importante mencionar nesse momento surgiu na década de 1960. É a estética da recepção, do historiador alemão Hans Robert Jauss (1921-1997). Entendida, em breves palavras, como "a acolhida alcançada por uma obra à época de seu aparecimento e ao longo da história” (Zilberman, 1989, p. 114), o autor considera a experiência estética como fundamental para se compreender como ocorre essa recepção. No entanto, chama a atenção ao dizer que essa experiência precisa ser melhor investigada na história da literatura, para que consiga responder questões relacionadas à arte e natureza, à forma e conteúdo, à imitação e criação, ao significado da obra e ao conhecimento que, segundo ele, são pouco problematizados. Concentrava-se muito na história das obras e dos artistas que na experiência estética e a sua recepção, ou seja, em interpretar esta experiência por dois meios: entender o significado e o efeito que o texto provoca no leitor, ou compreender como se desenvolveu o contexto histórico do qual o texto foi produzido, o que provoca diferentes recepções e interpretações pelos leitores.

No pensamento aqui proposto, Jauss (2002) propõe uma forma de analisar a experiência do leitor com textos, que poderia, no entanto, auxiliar a compreender como ocorre essa recepção. Primeiramente, é preciso diferenciar e estabelecer uma comunicação entre o leitor e o texto, isto é, "entre o efeito ${ }^{8}$, como o momento condicionado pelo texto, e a recepção, como momento condicionado pelo destinatário” (p. 73, grifo do original), para que se possa produzir sentido ao texto e a experiência do leitor e, consequentemente, o seu significado.

Ao refletir sobre essa visão da estética proposta por Jauss, Zilberman (1989) chama a atenção ao fato que, nessa tentativa de reformulação da história da literatura, Jauss defendia a relação dialógica entre o leitor e o texto, o qual era fundamental para que essa história se atualizasse com os resultados das leituras feitas nas obras por diferentes leitores. No entanto, ao contrário de Jauss que não considerava que a experiência estética iniciava pelo entendimento e interpretação do significado de uma obra, a autora esclarece que essa experiência pode ser entendida como:

[...] fruto do relacionamento da obra e o leitor, é o aspecto fundamental de uma teoria fundada na recepção. Compõe-se de três etapas, inter-relacionadas: a poiesis, pois o recebedor participa da produção do texto; a aisthesis, quando este alarga o conhecimento que o destinatário tem do mundo; e a katharsis, durante a qual ocorre o processo de identificação que afeta as possibilidades existenciais do leitor. (Zilberman, 1989, p. 113)

Dito com outras palavras, Zilberman (1989) afirma que Jauss buscou elaborar uma teoria que pudesse superar os padrões do positivismo e idealismo do século XIX no campo da literatura, a qual estava fossilizada. Essa superação promoveria uma nova teoria da literatura, embora distante do estruturalismo, do marxismo e da psicologia, mas com aportes da arte e da história. Portanto, passaria a considerar essas duas áreas nas análises dos textos, fato esse que era incipiente na época (1970), até então, com o leitor. Ou seja, a estética da recepção considerava que o texto literário não podia ser compreendido sem a participação do seu leitor.

\subsection{A ESTÉTICA FILOSÓFICA}

Os principais filósofos da antiguidade -Platão, Aristóteles e Sócrates- não trataram exatamente da estética em suas obras, mas forneceram elementos que pudessem desenvolvê-la nas discussões a respeito da sensibilidade, da arte e do belo. Platão (447-374 a.C.) em suas obras O Banquete e Fedro deixa claro sua desconfiança pela arte, ao entendê-la como mera imitação do mundo das sombras/irreal/sensivel, tido como imperfeito, pois as aparências não eram verdadeiras. 
Nessa perspectiva, para que a arte fosse verdadeira, justa, algo bom e perfeito, deveria representar o mundo real (mundo das ideias). Considerava que a arte é bela se a mesma representa o justo, o verdadeiro, o perfeito. Ou seja, o belo, a princípio, não era relacionado à arte, pois fazia parte do mundo das ideias. Desse modo, ao estabelecer essa distância entre o belo e a arte, Platão entendia também que a arte, para ter as qualidades citadas anteriormente, deveria representar a perfeição, portanto, manifestar o mundo das ideias que ele tanto defendia. É por isso que alguns teóricos vão dizer que a estética para Platão era algo justo, verdadeiro, perfeito, e não a criação humana ou imitação (Jimenez, 1999; Vieira, Ferronato e Feldens, 2017).

$\mathrm{Na}$ origem de toda beleza, diz Platão, deve haver 'uma primeira beleza que pela sua presença torna bela as coisas que designamos por belas, qualquer que seja o modo como se faz essa comunicação'. E mais: pode dizer-se até que a estética nasceu no dia em que Sócrates soube responder a Hipias (no Hipias Maior) que o Belo não era um atributo particular de mil e um objetos; sem dúvida, homens, cavalos, vestuário, virgem ou lira, são coisas belas; mas, acima de tudo isso, existe a beleza em si. (Huisman, 1984, p. 16)

Para Greuel (1994) estética já vinha se esboçando nos discursos de Platão e Aristóteles. Ao mencionar Platão, afirma que para esse filósofo a arte não tinha grande importância, pelo fato de criar objetos (cópias) da realidade. Portanto, concebia o belo não como algo físico, mas relacionado à percepção e ao divino. Por isso que Platão não falou exatamente da estética. Na verdade, tentou descrever uma teoria do Belo.

Aristóteles (384-322 a.C.) divergia em alguns momentos de Platão. Para ele, a arte tinha na imitação, algo justamente que Platão criticava, a sua essência. Compreendia que o sensível tinha relação com a aparência, que possibilitava observar o mundo natural e estava relacionado ao conhecimento do indivíduo (Pontes, 2013). Então, para Aristóteles, o belo se refere tanto a perfeição quanto a criação da arte pelo indivíduo. Entende que essa arte deve buscar uma proporção entre suas partes da obra, isto é, uma simetria, um "arranjo estrutural de um mundo encarado no seu melhor aspecto" (Huisman, 1984, p. 26), o que implicaria no belo defendido por esse filósofo. Diante disso, considerava:

[...] a mímese e a poésis para tratar da produção em arte. A mímese é entendida como imitação da atividade produtiva da natureza e poésis, entendida como a criação de algo novo. O conceito de mimese é deslocado do sentido de cópia, que recebia no sistema filosófico platônico, para o de representação e transformação. (p. 94)

Além disso, Aristóteles, em suas obras Arte Poética e Poética, busca abordar a arte por meio da poesia, comédia e epopeia, salientando suas formas de produção e as caracterizando como artes de imitação. Embora esse filósofo discorde de Platão por afirmar que o Belo não surge da experiência, se aproxima dele ao dizer que o belo é aquilo que é perfeito, algo verdadeiro, portanto, belo é algo do bem. Aristóteles, semelhante a Platão, não se debruça exatamente sobre uma teoria estética, mas dá indícios da mesma ao falar sobre a arte e a poética em suas obras.

A esse respeito, Vázquez (2005) faz uma importante contribuição: tanto em Platão quanto em Aristóteles é possível perceber um efeito da recepção estética em suas obras, especificamente em A República e em Poética, ao dizer que na primeira, a poesia seduz os seus leitores a contemplar as ideias, isto é, a verdade. Em Aristóteles, a tragédia purificava o leitor de suas paixões quando esse lia as cenas que ocorriam nas histórias.

Para Kant (2012) a representação subjetiva de um objeto que se relaciona com o indivíduo é a natureza estética dessa representação. Com esse raciocínio, afirma que para conferir se determinado objeto é belo ou não, parte-se para a representação do mesmo, tendo na imaginação, no entendimento e no sentimento de prazer ou desprazer elementos para esse julgamento (experiência estética). Desse modo, o juízo de gosto não se refere ao conhecimento, mas a representação desse objeto, que pode ser da experiência estética.

Entretanto, Kant (2012) discorda de padróes que determinam o que seja belo, pois, para ele, esse termo não precisa ser regido por regras, por estar relacionado a objetos da natureza, portanto, não precisa ter conceito para agradar alguém. Dessa afirmação, ressalta que todo juízo de gosto emitido pelo indivíduo nessa perspectiva é estético, pois envolve o seu sentimento, e não o conceito do objeto analisado. 
Na perspectiva de Kant (2012), o ideal de belo está ligado à imaginação do indivíduo. Consequentemente, afirma que:

[...] a beleza para a qual deve ser procurado um ideal não tem de ser nenhuma beleza vaga, mas uma beleza fixada por um conceito de conformidade a fins objetiva; consequentemente, não tem de pertencer a nenhum objeto de um juízo de gosto totalmente puro, mas ao de um juízo de gosto em parte intelectualizado. (p. 75)

Logo, compreende que a arte é bela se provocar prazer e emoções agradáveis no indivíduo. Consequentemente, passa a ser entendida como uma arte estética, dotada de sensibilidade e produção de sentidos. Ao contrário disso, a arte que não provoca esses sentimentos não é bela, tampouco estética.

Ao refletir sobre o belo e a arte, Kant (2012) compreende que não há uma ciência do belo, pois não há dados científicos que comprovem o que algo pode ser belo ou não. Em adição a essa afirmação, pontua que arte não é ciência, portanto, o juízo de gosto não é científico. Compreende a arte como técnica artística artes do fazer - e, nesse sentido, fica claro a sua afirmação de que arte é criação humana, porém, pode ser encontrada na natureza, pois, como dito anteriormente, não há regras para aquilo que é arte.

No entanto, Hegel (2001) não considera que a estética se limita ao belo da arte, embora afirme que o belo artístico é superior a beleza da natureza, pelo simples fato do primeiro nascer do espírito. Por esse ângulo, se opõe a Kant ao pontuar que a arte é histórica e uma atividade humana, com finalidade e produzida/destinada pelos sentidos do homem. Portanto, Hegel (2001) entende que a arte não é imitação do belo, mas produto da razão e histórico:

O belo é a ideia enquanto unidade imediata do conceito e de sua realidade, isto é, ele é a ideia na medida em que esta sua unidade está presente de modo imediato no aparecer sensível e real. A existência inicial da ideia é, pois, a natureza e a primeira beleza é a beleza natural. (p. 131, grifos do original)

Com tal enunciado, Hegel (2001) compreende que a beleza é a ideia, portanto, verdadeira. Compreende que o belo é determinado como aparência sensível dessa ideia. Por fim, afirma que se o objeto é belo, o mesmo deixa aparecer o seu conceito realizado na relação do eu com o objeto, pois, nas palavras desse filósofo, "o eu deixa igualmente de ser apenas a abstração da atenção, do intuir sensível. [...] Ele se torna em si mesmo concreto nestes objetos na medida em que se transforma para si mesmo" (Hegel, 2001, p. 128).

\subsection{A ESTÉTICA SOCIOLÓGICA MARXISTA}

Neste momento, busca-se ampliar um pouco mais a concepção de estética e a sua relação com o campo educacional. Para isso, o artigo traz para o debate a estética marxista. Os sociólogos, particularmente os marxistas, sempre se interessavam pelos problemas estéticos relacionados às teorias e práticas artísticas do homem com a realidade. As ideias estéticas de Marx estão relacionadas à sua concepção de homem e sociedade, tendo na arte o pressuposto para a apropriação humana das coisas e da natureza (Vázquez, 2011).

Mas então, qual o significado de estética sociológica?

Enquanto ciência, a estética para Vázquez (2011) tem como principal objetivo tratar da arte como atividade humana, criativa e histórica. Busca identificar a estrutura da obra artística, suas principais categorias e a sua relação com o homem e o mundo. $\mathrm{O}$ autor ressalta que a estética marxista se importa mais com o resultado final do trabalho artístico elaborado pelo homem - produto - e bem menos pelo seu processo. Com esse viés, se a arte tem utilidade e faz uso de suas qualidades estéticas, consequentemente, satisfaz a necessidade humana.

A obra de arte é produto de um trabalho peculiar. Esse trabalho produz também um objeto útil que satisfaz uma necessidade humana, a saber, a necessidade de se expressar, afirmar e comunicar [...] O homem produz obras de arte por uma necessidade, obras que têm um valor de uso peculiar, de acordo com a sua capacidade para satisfazer tal necessidade [...] A utilidade da obra de arte, seu valor de uso, acha-se condicionada por determinadas qualidades do objeto, qualidades que o homem deposita numa matéria dada mediante um processo de criação. $\mathrm{O}$ valor de uso condicionado por essas qualidades não existe, 
portanto, sem o homem e só tem sentido para ele quando se acha em relação com uma necessidade humana. (Vázquez, 2011, p. 180-181)

Nesse sentido, entende-se que, mesmo sendo uma epistemologia autônoma e, embora seja muito ainda vinculada a filosofia do belo, a estética pode se debruçar, quando necessário, em outras teorias, como a psicologia, a sociologia, a linguística, a teoria Histórico-Cultural, pois há autores que permitem fazer esse diálogo, como o próprio Vigotski, Marx e Vázquez, por exemplo, ao permitirem ampliar o conceito de estética na pesquisa em educação.

Nessa direção, Vázquez (1999) ressalta que um dos objetos da estética deve ser a apropriação da realidade e, ao considerá-la, o seu conceito também deve ser ampliado. Isso significa dizer que é possível estender a sua concepção a outros objetos que, sob determinadas condiçóes e ações, apresentam qualidade estética. Com efeito, "estética é a ciência de um modo específico de apropriação da realidade, vinculado a outros modos de apropriação humana do mundo e com as condições históricas, sociais e culturais em que ocorre" (Vázquez, 1999, p. 47).

Ao falar sobre o marxismo contemporâneo, Vázquez (2011) relaciona a arte à ideologia ${ }^{9}$, pois desde o surgimento de estudos marxistas sobre a estética artística, isto a partir do final do século XIX, a arte é vista por eles em sua natureza ideológica, isto é, como parte de uma sociedade dividida em classes, na qual a expressão artística deve ser composta por ideais políticas, morais e religiosas, mas, sem se reduzir a um mero fenômeno ideológico.

Esse aprofundamento na natureza específica da arte, porém, sem desligá-la do aspecto ideológico, fez com que os marxistas concebessem a arte como forma de conhecimento, como foi o caso de Marx. Para esse pensador, uma ideologia falsa poderia afetar negativamente a verdade artística expressa na obra.

Ora, o artista, ao criar a obra de arte, aproxima-se da realidade modificando-a, porém, sem dissociá-la de seu conteúdo ideológico. É nesse sentido que a arte é tida como forma de conhecimento para os marxistas. Compreendiam que a verdade representava o real, isto é, a realidade sócio-histórica e concreta do indivíduo que vive na sociedade.

Vázquez (2011) completa esse pensamento ao afirmar que a arte reflete a essência do real e cria uma nova realidade. Então, é possível afirmar que a arte não apenas reflete ou expressa a realidade, mas, ela a torna presente devido ao seu caráter expressivo e criador.

A tese de Marx a respeito da arte estabelece uma relação negativa dela com o capitalismo, na qual este último não favorece o desenvolvimento e a produção artística, pois considera que toda produção material, inclusive a arte, submetida à produção capitalista, se torna uma atividade produtiva.

Na visão marxista, quando a obra de arte se torna mercadoria, enquanto objeto de valor de troca, a mesma se submete ao capitalismo, o que a desumaniza, fazendo-a perder sua qualidade estética. Com efeito, "o valor de troca de uma mercadoria, diferentemente do valor propriamente estético, não leva em conta as propriedades sensíveis, a forma do objeto" (Vázquez, 2011, p. 183).

Nas palavras de Vázquez (2011), a liberdade criadora do artista é afetada quando sua obra se encontra sob as leis do capitalismo. Diante disso, sua criação fica limitada, às vezes negada, tornando-se uma mera mercadoria. $\mathrm{O}$ artista deixa de criar segundo uma necessidade interna e passa a criar para uma necessidade externa - mercado. Ao agir dessa forma, deixa de expressar sua liberdade criadora e sensibilidade estética. Ou seja, ao perder a criatividade, a arte deixa de ser sensível e, consequentemente, perde seu valor estético e artístico. Todavia, o artista pode tentar escapar dessa hostilização do capitalismo à arte desdobrando a sua atividade criadora, ou seja, criando segundo sua necessidade interna de expressão:

A arte é trabalho, mas um trabalho verdadeiramente criador [...] satisfaz a necessidade do homem de humanizar o mundo que lhe rodeia e de enriquecer com o objeto criado sua capacidade de comunicação. Nesse sentido, a arte é superior ao trabalho. (Vázquez, 2011, p. 173) 
É essencial assinalar que na visão marxista esse valor de troca desumaniza o homem e o próprio objeto, ao perder a sua significação humana: coisificam-se, alienam-se. Em suma, a mercadoria deixa de estar em relação com a necessidade humana quando se torna objeto de troca, ao se tornar um objeto desumanizado. Nesse entendimento, a obra de arte é compreendida como mercadoria de troca.

Para Lukács (1978), a arte possibilita ao indivíduo se relacionar com o mundo, bem como os sentidos produzidos por ele que ajudam a mediar essa relação. Nessa ideia, a arte revela a qualidade estética para a vida humana, implicando, portanto, numa relação estética entre o homem e a humanidade. Defende a tese de que a arte deve representar a luta de classes, a estrutura classista de uma sociedade, além da subjetividade de seu criador. Ao refletir a realidade objetiva, a arte evita ser extinta no âmbito da sociedade.

No entanto, esse autor oferece indícios para uma contribuição para a reação estética mencionada por Vigotski (1998) ao afirmar que a emoção provocada pela arte leva o indivíduo a reviver eventos por ele vividos ao longo de sua vida, "tanto no caso em que assista a obras que representam o presente, como no caso em que a força da arte oferece a sua experiência fatos que lhe são distantes no tempo ou no espaço, de outra nação ou de outra classe" (p. 289). Ou seja, o indivíduo vivencia o passado histórico e o presente, para que possa refletir sobre o desenvolvimento futuro de sua vida e a tomar decisões.

Nesse processo, o prazer artístico recebido pelo indivíduo o enriquece e, ao mesmo tempo, o transforma e reforça a sua comoção (Lukács, 1978). Então, a arte, sendo reflexo da realidade objetiva, medeia e provoca nele a necessidade de desenvolvimento e, consequentemente, o desenvolvimento histórico e social da sociedade. Dito isso, esse reflexo estético, na visão do autor, produz novas realidades que transformam o indivíduo do seu eu individual para o seu eu coletivo, na produção da obra de arte. Desse modo, a arte se transforma em autoconsciência humana, pois, ao se apropriar de uma realidade, esse indivíduo cria para si uma autoconsciência que não é separada do mundo exterior. Com efeito, a autoconsciência pode ajudar a compreender os fenômenos artísticos que se desenvolvem no percurso histórico da humanidade:

O conteúdo da obra de arte é a experiência que o indivíduo faz de si mesmo na ampla riqueza de sua vida na sociedade e da sua existência como parte e movimento do desenvolvimento da humanidade [...] No prazer estético, o sujeito receptivo imita aquele movimento que recebe a sua forma objetiva na criação da individualidade da obra de arte: uma 'realidade' que, no sentido da diferenciação, é mais intensa do que a experiência obtida na própria realidade objetiva e que, precisamente nesta intensidade, revela imediatamente a oculta essencialidade real. (Lukács, 1978, p. 292)

Essa representação da realidade pelo viés marxista, que serve à verdade e reflete a essência dos fenômenos humanos, considera a arte como meio específico de conhecimento. De todo modo, é possível dizer que a ideologia e o realismo na obra de arte são os principais temas pelos quais a estética marxista se interessará.

\subsection{A ESTÉtica NA FORMAÇÃo DE PROFESSORES}

A análise teórica desenvolvida nos tópicos anteriores conduz a dizer que é possível pensar em uma estética na formação de professores. Sobre isso, para Loponte (2017), a formação estética docente possibilitaria aos professores terem contato com diferentes linguagens artísticas, para que o "docente pudesse educar-se, humanizar-se, sensibilizar-se, passando a enxergar os alunos com outro olhar” (p. 434). Ou seja, ter contato com essa diversidade leva o indivíduo a ampliar a sua relação com o outro, as interpretações da realidade a sua volta, além de elevar o seu conhecimento cultural.

A esse respeito, a autora assevera que a estética não deve se referir unicamente à beleza, mas à experiência desenvolvida a partir de práticas pedagógicas artísticas. Ou seja, deixa claro que é importante evitar convenções clássicas e tradicionais que defendem a estética como um único ideal de beleza, ao tratar de experiências educativas que envolvam a arte.

Assim como Duarte (1981), Carvalho (2013) e Neitzel (2013) também entendem que a estética na educação deve estar voltada ao esmero dos sentidos humanos e que a escola seja bem mais que uma instituição 
educativa: que seja um espaço para a produção e disseminação de um conhecimento sensível. Desse modo, em consonância com Pareyson $(1993,1997)$, afirmam que esse entendimento permite conceber a educação como um processo formativo que muito contribui para a formação dos sentidos e da percepção mais ampla da realidade pelo indivíduo.

Nesse sentido, a arte e suas diversas manifestações possibilitam ao indivíduo ampliar o seu entendimento da realidade, bem como sua sensibilidade e reflexão para questões a sua volta (Carvalho y Neitzel, 2013), ou seja, ao interagir com a arte, o indivíduo pode ter na experiência estética um "meio pelo qual percebe melhor a si mesmo e seu entorno" (p. 1024).

Com essa visão, as autoras defendem que a formação estética leva o professor a ter um olhar mais sensível às diferentes e variadas mazelas que assolam a educação brasileira. Desse modo, o contato com a diversidade artística, além de promover novas experiências ao professor, o torna mais sensível para as situações educativas em sua prática pedagógica. Esse acesso à arte, que pode ocorrer por diferentes meios, como a música, a pintura entre tantas outras, o leva a compreender melhor o contexto do qual faz parte, vive e se constitui enquanto sujeito histórico.

Outro trabalho bastante interessante, que aborda a categoria estética no campo educacional, é o de Rosito (2017). Em seu estudo, a partir de análises de algumas obras do pensador brasileiro Paulo Freire (1921-1997), compreendeu que suas obras, especificamente Pedagogia da Esperança e Pedagogia do Oprimido, trazem dois elementos - desenvolvimento da autonomia e emancipação - que permitem ter um olhar estético e, portanto, mais sensível para com a educação. A autora afirma que a análise feita por ela possibilitou inferir que esses elementos, quando analisados esteticamente, podem ser relevantes para a melhoria da educação e sociedade.

A partir dessa reflexão, Rosito (2017) enumera 4 possibilidades interessantes para se utilizar a estética na educação:

a) toda leitura do mundo é estética, pois o indivíduo, a partir de suas experiências de vida constrói sentidos e significados da realidade a sua volta, ampliando o seu conhecimento de mundo e o aprendizado.

b) ao se relacionar com o outro, o indivíduo constrói um olhar estético, isto é, a relação entre o professor e o aluno precisa ser afetuosa, respeitosa, cordial e dialógica.

c) a linguagem enquanto estética, isto é, sem linguagem não há como o indivíduo se comunicar e participar enquanto sujeito histórico, pois é impossível dissociar linguagem da experiência do indivíduo com a leitura e a escrita.

d) a estética da alteridade. Significa dizer que a construção do olhar do sujeito na relação com o outro é estética, pois envolve a sensibilidade.

Rosito (2017) parte da ideia de que é importante que a educação seja humanizadora, que proporcione ao indivíduo construir conhecimentos científicos e artísticos. Mas, para que isso aconteça, entendo que é necessário que a educação seja não apenas um ato criador e crítico, mas, sobretudo, seja baseada em um ensino desenvolvente, que possibilite ao educando desenvolver seu pensamento teórico e a sua aprendizagem. Assim, nessa dimensão estética, os conhecimentos construídos podem ser elaborados ou recriados por meio de novas experiências.

A autora chega à conclusão de que as obras de Paulo Freire permitem entender que todo trabalho humano tem a sua beleza e, na medida em que o indivíduo vai construindo a sua experiência, desenvolve a sua autonomia e amplia a sua capacidade de reflexão, tornando-se mais crítico e participativo, ou seja, parte de uma consciência ingênua para uma consciência crítica e, consequentemente, emancipadora. Destaca que é importante o professor considerar em suas práticas pedagógicas esse olhar sensível para com o aprendizado do educando. Além de romper com um paradigma de ensino tradicional, provocará no aluno o gosto de aprender e criar um olhar estético, não ficando apenas decodificando leituras, mas também as criando e as interpretando em novos contextos, desenvolvendo seu pensamento.

Portanto, ampliar o conceito de estética a partir da pesquisa bibliográfica realizada acerca do tema, em diálogo com diferentes bases teóricas foi um dos objetivos nesta pesquisa. Com efeito, compreender a extensa 
e densa literatura que trata de arte e estética não impossibilita ampliar seus significados na produção de conhecimento que, por sua vez, está em constante movimento.

\section{CONSIDERA\#O\#ES FINAIS}

A partir da pesquisa interpretativa realizada, é possível afirmar que a arte amplia o entendimento da cultura da qual faz parte o indivíduo, levando-o a ser mais crítico e participativo. As diferentes experiências estéticas com a arte pode fazer com que esse indivíduo amplie o seu aprendizado, fundamental para que avance no processo formativo e, consequentemente, no conhecimento.

Nas análises construídas, não há dúvidas de que o indivíduo, ao produzir arte, deixa nela registrada a sua cultura, o seu trabalho, as suas ideias e conhecimentos de mundo, enfim, deixa gravado nela a sua vida. $\mathrm{O}$ objeto por ele criado só tem sentido na relação social entre ele e o próprio homem. É por isso que a arte não apenas expressa emoções, mas representa a realidade humana, materializada no objeto estético.

$\mathrm{Na}$ educação, a arte pode desempenhar importante papel ao proporcionar ao estudante o desenvolvimento de sua capacidade criadora e, consequentemente, que possa potencializar a sua percepção de mundo. Por meio da arte o estudante jovem ou adulto objetiva a sua realidade na criação estética, uma vez que essa criação, entendida como trabalho humano, carrega uma consciência crítica da vida desse sujeito. Em outras palavras, a arte humaniza e transforma não apenas o real, retratada no objeto artístico, mas proporciona ao estudante a compreender melhor o seu meio cultural, importante para questionar a sua própria realidade.

Os dados revelaram ainda que estética apresenta diferentes concepções no percurso histórico científico, ora se convergindo com o campo educacional, ora se distanciando desse. Porém, ficou evidente nas análises que outros objetos, pensamentos ou atividades (não apenas obras artísticas), também podem ser belos, desde que apresentem alguma qualidade estética, ou seja, que ofereçam harmonia, coerência e equilíbrio em suas formas.

Com esse raciocínio, entende-se que durante a trajetória escolar ou acadêmica, pode ocorrer dos estudantes jovens ou adultos não quererem produzir um objeto ou atividade apenas por produzir, eles podem querer fazê-los bem feitos, e isso responde a uma necessidade prática de produção material que os acompanha no percurso histórico da humanidade. Sendo expressão de algo bem definido, coerente e bem resolvido, pode ser entendido como expressão de beleza, uma vez que apresenta qualidade estética.

Em conclusão, se um estudante busca, por exemplo, corrigir ou solucionar problemas que apareçam em sua escrita (corrigir erros ortográficos e conhecer novas palavras a partir da leitura e reescrita de textos verbais e visuais), melhorando os seus processos de leitura e escrita, tornando o seu texto bem feito, organizado e coerente, o seu texto pode ser considerado belo, pois apresenta caráter de obra bem feita, harmoniosa; portanto, bela.

As referências analisadas fazem parte da importante literatura acerca da estética filosófica e sociológica nas ciências humanas. Contudo, devido à extensão deste manuscrito, não discutiu-se autores contemporâneos. Diante disso, cumprindo um dos seus objetivos, sugere-se outros estudos internacionais que abordem esses autores, uma vez que contribui para ampliar a produção de conhecimento a respeito desse tema, não esgotando a discussão proposta neste artigo.

\section{REFERE\#NCIAS}

Araújo, G. C. (2018). O letramento estético na consolidação dos processos de leitura e escrita de jovens e adultos da Educação do Campo (Tesis Doctoral). Universidade Estadual Paulista Júlio de Mesquita Filho, Marília, São Paulo. Recuperado de: https://repositorio.unesp.br/handle/11449/180257.

Araújo, G. C., y Oliveira, A. A. (2015). Sobre o conceito de arte e a formação escolar na Educação de Jovens e Adultos. Revista HISTEDBR On-line, 15(63), 189-209. Recuperado de: https://doi.org/10.20396/rho.v15i63.8641178. 
Bakhtin, M. (1981). Marxismo e filosofia da linguagem. (Trad. M. Lahud y Y. Frateschi) (2a. ed.). São Paulo: Editora Hucitec.

Bakhtin, M. (2002). Questôes de literatura e de estética: a teoria do romance. (Trad. A. Bernardini, J. Júnior, A. Júnior, H. Nazário y H. Andrade) ( 5 a ed.). São Paulo: Editora Hucitec/Annablume.

Bakhtin, M. (2011). Estética da criação verbal (21ª . ed.). São Paulo: Martins Fontes.

Barbosa, A. M. (1998). Tópicos Utópicos. Belo Horizonte: C/Arte.

Barbosa, A. M. (2008). Inquietações e mudanças no ensino da arte ( $5^{a}$ ed.). São Paulo: Cortez.

Barbosa, A. M. (2012). A imagem no ensino da arte: anos 1980 e novos tempos ( $8^{\text {a }}$. ed.). São Paulo: Perspectiva.

Bertoloto, J. S., Campos, M. G., y Monteiro, E. S. (2017). O ensino da arte na construção de uma identidade cultural no Brasil. Revista de Educação Pública, 26(62), 583-601. Recuperado de: http://dx.doi.org/10.29286/ rep.v26i62/2.5500.

Bogdan, R. I., y Biklen, E. (1994). Investigação qualitativa em educação. São Paulo: Atlas.

Carvalho, C., y Neitzel, A. A. (2013). A estética na formação de professores. Revista Diálogo Educacional, 13(40), 1021-1040. Recuperado de http://dx.doi.org/10.7213/dialogo.educ.13.040.DS10.

Duarte, J. F. (1981). Fundamentos estéticos da educação. São Paulo: Universidade Federal de Uberlândia.

Erickson, F. (1985). Qualitative methods in research on teaching. Michigan: The Institute for Research on Teaching.

Ferraz, M. H., y Fusari, M. F. (2010). Metodologia do ensino de arte. São Paulo: Cortez.

Greuel, M. V. (1994). Da “teoria do belo" a "estética dos sentidos”: reflexões sobre Platão e Friedrich Schiller. Anuário de Literatura, 2(2), 147-155. Recuperado de https://doi.org/10.5007/\%25x

Haynes, D. J. (2002). Bakhtin and the visual arts. En Smith, P. y Wilde, C. (Eds.). A companion to art theory (pp. 292-302). New Jersey: Blackwell Publishing. Recuperado de https://doi.org/10.1002/9780470998434.ch24

Hegel, F (2001). Cursos de estética. (Trad. M. A. Werle) (2ª. ed.). São Paulo: EDUSP.

Hernández, F. (2000). Cultura visual, mudança educativa e projeto de trabalho. Porto Alegre: Artmed.

Huisman, D. (1984). A estética. Lisboa: Edições 70.

Iavelberg, R. (2003). Para gostar de aprender arte: sala de aula e formação de professores. Porto Alegre: Artmed.

Jauss, H. R. (2002). A estética da recepção: colocações gerais. En Lima, L. C. (Org.). A literatura e o leitor: textos de estética da recepção (pp. 67-84). Rio de Janeiro: Paz e Terra.

Jimenez, M. (1999). O que é estética? (Trad. F. Moretto). São Leopoldo: Editora UNISINOS.

Kant, I. (2012). Critica da faculdade do juizo (Trad. V. Rohden y A. Marques) ( $3^{\mathrm{a}}$. ed.). Rio de Janeiro: Forense Universitária.

Loponte, L. G. (2017). Tudo isso que chamamos de formação estética. Revista Brasileira de Educação, 22(69), 429-452. Recuperado de: http://dx.doi.org/10.1590/S1413-24782017226922.

Lukács, G. (1978). Introdução a uma estética marxista (Trad. C. N. Coutinho y L. Konder). Rio de Janeiro: Civilização Brasileira.

Martins, M. C. (2011). Arte, só na aula de arte?. Educação, 34(3), 311-316.

Marx, K., y Engels, F. (1974). Sobre literatura e arte (4ª. ed.). Lisboa: Editorial Estampa.

Osborne, H. (1968). Estética e teoria da arte. São Paulo: Cultrix.

Pareyson, L. (1993). Estética: teoria da formatividade (Trad. E. Ferreira). Petrópolis: Vozes.

Pareyson, L. (1997). Os problemas da estética (3a . ed.). São Paulo: Martins Fontes.

Pontes, G. M. (2013). Arte na educação da infância: saberes e práticas da dimensão estética (Tesis Doctoral). Universidade Federal do Rio Grande do Sul, Porto Alegre. Recuperado de: https://lume.ufrgs.br/ handle/10183/70604.

Rosito, M. M. (2017). A estética da Pedagogia da Esperança: contribuições à formação de professores. Reflexão e Ação, 25(2), 9-26. Recuperado de: http://dx.doi.org/10.17058/rea.v25i2.8972. 
Vázquez , A. (1999). Convite à estética. Rio de Janeiro: Civilização Brasileira.

Vázquez, A. S. (2005). De la estética de la recepción a una estética de la participación. Ciudad de México: Universidad Autónoma de México.

Vázquez, A. S. (2011). As ideias estéticas de Marx (Trad. C. N. Coutinho) (3ª ed.). São Paulo: Expressão Popular.

Vieira, J., Ferronato, C., y Feldens, D. (2017). A produção estética da docência: macro e microdimensões. Eccos, 19(43), 39-51. Recuperado de https://doi.org/10.5585/eccos.n43.7258.

Vigotski, L. S. (1998). Psicologia da arte. São Paulo: Martins Fontes.

Vigotski, L. S. (2007). A formação social da mente: o desenvolvimento dos processos psicológicos superiores (Trad. J. Neto, L. Barreto y S. Afeche) (7ª ed.). São Paulo: Martins Fontes.

Vigotski, L. S. (2009). Imaginação e criação na infância: ensaio psicológico (Trad. Z. Prestes). São Paulo: Ática.

Zilberman, R. (1989). Estética da recepção e história da literatura. São Paulo: Ática.

\section{Notas}

1 Para conferir o estudo na íntegra, se recomenda a leitura da pesquisa de doutorado de Araújo (2018).

2 No que se refere às definições de arte, Pareyson (1997) destaca 3 que, segundo ele, são as mais tradicionais: arte como fazer (arte produzida na antiguidade; arte manual, executora, fazer); arte como conhecer (como conhecimento, expressão da realidade); arte como expressão (beleza da expressão, do sentimento).

3 Cf. Jimenez (1999), Vieira, Ferronato e Feldens (2017), Kant (2012), Greuel (1994), Hegel (2001), Huisman, (1984), Platão nas obras "O Banquete" e "Fedro" e Aristóteles em suas obras "Arte Poética" e "Poética".

4 Enquanto disciplina e área do saber, Estética surgiu pela primeira vez no século XVIII com o filósofo alemão Baumgarten, que foi o pioneiro em construir a primeira teoria estética, vinculada ao sensível e a percepção (Vázquez, 2005; Jimenez, 1999).

5 É uma das categorias centrais na estética de Bakhtin, pela qual o autor e a personagem são inseparáveis. Nesse raciocínio, alguns conceitos são destacados por Bakhtin: distância, excedente de visão, horizonte e ambiente.

6 Trecho original da tradução: "He was concerned with how humans give form to their experience: how they perceive an object, text, or another person, and how they shape that perception into a synthesized whole" (Haynes, 2002, p. 293).

7 Trecho original da tradução: "Bakhtin's approach to aesthetics is thus unique. It is based not only on categories such as the aesthetic (the aesthetic attitude or aesthetic object) or aesthetic values (truth, goodness, or beauty), but also on the phenomenology of self-other relations, relations that are embodied in actual bodies, in space and time" (Haynes, 2002, p. 294).

8 Entendido como "resposta ou reação motivadora pelo texto no leitor" (Zilberman, 1989, p. 112).

9 Segundo Marx, ideologia se refere a um sistema de ideias que se referem à consciência que os homens têm de determinada época da história. 